\title{
口腔由来正常上皮細胞およびロ腔癌細胞の無血清培養下での增殖に
} 及ぼす EGF，FGF の影響ならびにこれら細胞における受容体解析

\author{
尾崎輝彦・岡本哲治・數本正文 \\ 明見能成一高田和彰
}

\section{Effects of epidermal growth factor and fibroblast growth factor on the growth of normal epithelial cells and oral cancer cells in serum-free culture and the expression of growth factor receptor on the cells}

\author{
Teruhiko Osaki - Tetsuji Окамото - Masafumi Yabumoto \\ Yoshinari MYOKEN Kazuaki TAKADA
}

\begin{abstract}
Wi have established scrum-free culture system for normal epithelial cells and cancer cells derived from oral mucosa and the salivary gland. It was found that oral cancer cells were able to grow in a serum-free medium supplemented with insulin, transferrin, sodium selenite, 2-aminoethanol and 2-mercaptoethanol disignated RD5F as same as that in the medium supplemented with $10 \%$ FBS. On the other hand, normal epithelial cells were not able to grow in a serum-free medium supplemented with factors as above. Thus hormone and growth factor requirement for proliferation of normal epithelial cells were studied in a serum-frec medium. It was revealed that normal epithelial cells absolutely required EGF or FGF for the growth in a serum-free culture. Furthermore, we have studied effects of EGF and FGF on the growth of oral cancer cells in a serum-frec culture and expression of these factor receptors on the cell by radioligand receptor assay.

EGF stimulated growth of adenocarcinoma cells derived from the salivary gland (SAC) but inhibited that of squamous cell carcinoma (SCC) cells at the concentration which stimulate growth of other cells. FGF stimulated growth of SAC but did not have any effect on SCC cells. Furthermore, we could not find any significant differences in the expression of EGF and FGF receptors of these cells. Taken together, it was revealed that oral cancer cells exhibited lowered or lost requirement of EGF and FGF for growth compared to normal epithelial cells. These results strongly suggested the possibility that EGF and/or EGF receptor expressed in SCC: cells were functionally different from that of normal cpithelial cells.
\end{abstract}

Key words: epidermal growth factor（上伎成長因子）, fibroblast growth factor（線維芽細胞成 長因子), oral cancer cells (口腔嗝稩胞)

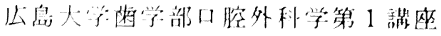

(主任：高田和彰教授)

Department of Oral and Maxillo-Facial Surgery
I, Hiroshima University, School of Dentistry (Chief: Prof. Kazuaki Takada)

受付日：平成 3 年 3 月 20 日 


\section{緒}

\section{言}

近年, growth factor やその受容体亡癌遗伝子産物之 の類似性 ${ }^{1,2)}$ が報告されている。また，正常細胞の悪性 転換に伴い growth factor 要求性の変化 ${ }^{3)}$ やの受容体 の異常 ${ }^{4)}$ に生じていることがあきらかにされている.

Todaro, Sporn らは, 腫瘍の自律增殖性は腫瘍細胞が 自ら自己增殖促進因子を産生する，あるいは増殖抑制因 子に対して応答異常が生じることにより発現されるとい ら autocrine 説 5 ,6) を提唱した。しかし，悪性腫瘍の大 部分は癌腫であるにもかかわらず，この仮説はおもに楾 維芽細胞や肉腫細胞を用いた研究結果に基ついている. そこで癌細胞の增殖動態並びに增殖のための growth factor 要求性を理解寸るためにはその母細胞である正常 上皮細胞を用いて比較㛟討する必要があると考える。し かし, 従来の培養方法では正常上皮細胞の培羕は非常に 困難であった。これは血清中に存在する transforming growth factor $\beta$ (TGF $\beta$ ) が正常上皮細胞の分化を促 進 線維芽細胞の增殖を促進 ${ }^{8)}$ することなどによると考えら れる。また，血清中にはホルモン， growth factor や他 の未知蛋白が多量に存在すること, さらに血清のロット によっても含まれる物質が異なる。したがって, 培地に 血清を添加した培着方法では細胞增殖に及ぼすホルモン や growth factor の影響を検索することは困難である。

一方, Sato ら ${ }^{9}$ は血清の主たる働きは増殖にとって必 要なホルモンや growth factor を細胞に供給すること であるといら仮説をもとに，基礎培地に既知の growth factor やホルモンを加えた無血清培地を用いて, 動物細 胞の增殖のみならず機能をも維持することに成功し無血 清培着法を確立した。

そこで本研究では，口腔癌細胞の細胞増殖動態を細胞 内分泌学的 ${ }^{100}$ にあさらかにするためにヒト口腔粘膜由来 正常上皮細胞とヒト唾液腺由来正常上皮細胞, ヒ上口腔 由来扁平上皮癌細胞とヒト唾液腺由来腺癌細胞の無血清 培着系を確立した。さらに, この系を用いて, epidermal growth factor (EGF) および fibroblast growth factor (FGF) の細胞増殖に及ぽす影響とその受容体解析を行 い以下の結果を得た

\section{材料および方法}

\section{1. 細胞增殖因子の細胞增殖に及ぼす影響とその受容 体解析}

1）無血清培地

口腔粘膜由来正常上皮細胞および唾液腺由来正常上皮 細胞の培養には modified MCDB153 (m'-MCDB 153) 培地 ${ }^{11)}$ を基礎培地として用いた。腔由来扁平上皮癌細
胞株および唾液腺由来腺癌細胞株はPRMI 1,640 medium $^{12)} \lesseqgtr$ Dulbecco's Modified Eagle medium ${ }^{13}$ ) (D $\mathrm{ME}$ ，以上極東製薬）を等量混和した培地（以下 $\mathrm{RD}$ と略す） ${ }^{14,15)}$ を基礎培地として用いた。培地とれそれに sodium pyruvate (片山化学) $110 \mu \mathrm{g} / \mathrm{ml}$, kanamycin sulfate $90 \mu \mathrm{g} / \mathrm{m} l$, aminobenzylpenicillin（以上明治製 菓) $90 \mu \mathrm{g} / \mathrm{ml}$, sodium bicarbonate (和光純薬) を RD に $2 \mathrm{mg} / \mathrm{ml}, \mathrm{m}$ 'MCDB $153 に 1.2 \mathrm{mg} / \mathrm{ml}, \operatorname{HEPES}$ (同) 仁化学) をRDに $15 \mathrm{mM}, \mathrm{m}$ '-MCDB 153 に3 mM 加光，脱イオン化および逆浸透に純化した水（Mill-Q reagent water system, Millipore, USA) を用いて $\mathrm{pH}$ 7.4 に調整し， $0.2 \mu \mathrm{m}$ フィルター (Acrocap, Gelman Scier.ce Inc., USA) で滤過減菌したものを使用した。

口腔粘膜由来正常上皮細胞の無血清培羕条件は上述の 培地に, cristalline bovine insulin $10 \mu \mathrm{g} / \mathrm{m} l$, human transferrin $2 \mu \mathrm{g} / \mathrm{ml}, 2$-aminoethanol $10 \mu \mathrm{M}$ (以上 SI GMA Chemical Co., USA), 2-mercaptoethanol 10 $\mu \mathrm{M}$ および sodium selenite $10 \mathrm{nM}$ (以上片山化学) る 加えた培地 ( $\mathrm{m}$ '-MCDB 5F), 唾液腺由来正常上皮細胞 には m'-MCDB5F (transferrinは $5 \mu \mathrm{g} / \mathrm{ml}$ とした) に さらにオレイン酸 [oleic acid (Sigma Chemical Co., USA) $\measuredangle$ fatty acid-free bovine serum albumin (Pentax, Miles laboratories, Inc. USA) 2:1のモル比となる ように調整 ${ }^{16)}$ した〕 $4 \mu \mathrm{g} / \mathrm{ml}$ を加えた m'-MCDB6F 培 地に牛脳抽出液を用いて初代培差を行った。

扁平上皮癌細胞之唾液腺由来腺癌細胞は RD6 F (transferrinは $5 \mu \mathrm{g} / \mathrm{m} l$ とした）を用いた。

これら細胞は以上の培地を用いて, TE HER 型 $\mathrm{CO}_{2}$ インキュベーター（平沢製作所）中， $5 \% \mathrm{CO}_{2}, 37 \mathrm{C}$ の 条件で静地培盖を行った。

2 ）正常細胞の分離培峑方法

口腔粘膜由来正常上皮細胞は口唇口蓋裂の手術時，あ るいは埋伏歯抜去時に切除した口腔粘膜より分離した。 皮下結合組織および皮下脂肪組織を可及的に除去した粘 膜を0.02\% EDTA (片山化学) を含主 Dulbecco's Ca, $\mathrm{Mg}$ free phosphate buffered saline (CMF-PBS, $\mathrm{NaCl}$ $8.0 \mathrm{~g}, \mathrm{NaHPO}_{4} 1.15 \mathrm{~g}, \mathrm{KCl} 0.2 \mathrm{~g}, \mathrm{KH}_{2} \mathrm{PO}_{4} 0.2 \mathrm{~g} / \mathrm{l}$, $\mathrm{pH} 7.2)$ 中で 30 分間処理した後， $0.05 \%$ トリプシン (Difco, USA) を含吉 CMF-PBS 中で $4 \mathrm{C}$ 下 1 㡺夜イ ンキュベートした。装日 $0.1 \%$ トリプンンインヒビター (type-II S, Sigma Chemical Co., USA) を含む m'MCDB 153培地中で, 关体顕微鏡（オリンパス，K.K. $\mathrm{Xr}$ 型）下に上皮と真皮を分離し自家製 ブラシにて基底 細胞を分離した ${ }^{17}$. 分離細胞はI 型コラーゲン (Cellmatrix type I-A，新田ゼラチン）コートした $60 \mathrm{~mm}$ 径プラスチックシャーレを用いて m’-MCDB 5 F に EGF $1 \mathrm{nM}$ あるいは FGF $500 \mathrm{pM}$ を添加した条件で 初代培塏を行った。

唾液腺由来正常上皮細胞は，腫瘍患者の頸部郭清時に 
摘出した病理組織学的に正常な顎下腺より分離した。 CMF-PBS および $70 \%$ ェタノールで組織を消毒後細切 し、コラーゲンコートした $60 \mathrm{~mm}$ 径プラスティックシ ヤーレに m’-MCDB 6 F に EGF $1 \mathrm{nM}$ あるいは FGF $500 \mathrm{pM}$ を添加した条件で組織片培養を開始した。

扁平上皮癌細胞株は当科で樹立した UEDA ${ }^{18)}$, NAKATA $^{19)}$ ，Kanetsuki および外陰部由来扁平上皮癌 $\mathrm{A} 431^{20}$ （DeLarco 博士より供与）を用いた。唾液腺由 来腺癌細胞株には $\mathrm{HSG}^{21}$ および $\mathrm{HSY}^{22}$ ) (德島大学雷学 部口腔外科学第 2 講座佐藤光信教授より供与）と当科で 樹立した腺様裂胞癌由来細胞株 $\mathrm{ACC}^{23)}$ を用いた。

3）無血清培差下での細胞增殖能の検索

扁平上皮癌細胞ならびに唾液腺由来腺癌細胞の增殖能 を $\mathrm{RD} 6 \mathrm{~F}$ と $10 \%$ 牛胎児血清 (MA Bio-rpoduct, USA) 添加時て比較した。対数增殖期の細胞を $0.05 \%$ トリプ シン, $0.04 \%$ EDTA を含む CMF-PBS（トリプシン）

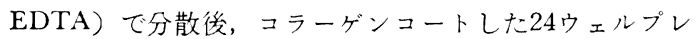
ート (Falcon, USA) に1ウェルあたり $2 \times 10^{4} / \mathrm{ml}$ の 細胞密度で植え込んだ。翌日から24時間ごとにコールタ 一カウンター (Coulter Electronics, England) にてそ の細胞数を計測した。

4）正常上皮細胞の增殖に及ぼす EGFならびに FGF の影響

継代 9 代目の口腔粘膜由来正常上皮細胞扣よび継代 3 代目の唾液腺由来正常上皮細胞を, コラーゲンコートし た 24 ウェルプレートに $1 \times 10^{4} / \mathrm{ml}$ の細胞密度で植え込 み, 各濃度の EGF (mouse EGF, Receptor Grade, Collaborative Research, Inc., USA) あるいは acidic FGF を加え，10日後に細胞数を計测した。なお，培地 は2 日に 1 回交換し，その都度これら因子も加えた。ま た acidic FGFは牛脳抽出液よりへパリンセファロース アフィニティークロマトグラフィー (Pharmcia Fine Chemical, Sweden) さらに逆相系高速液体クロマトグ ラフィーを用いて精製し24)実験に供した。

さらに口腔粘膜由来正常上皮細胞のホルモンならびに growth factor 要求性を colony assay 法を用いて検索 した. m'-MCDB + insulin ( I ), m'-MCDB 153+transferrin (T), m'-MCDB $153+\mathrm{T}, \mathrm{m}$ '-MCDB $153+5 \mathrm{~F}$, さらに，それぞれに EGF $10 \mathrm{ng} / \mathrm{ml}$ あるいは acidic $\mathrm{FGF} 500 \mathrm{pg} / \mathrm{ml}$ を添加した条件で，コラーゲンコート した $60 \mathrm{~mm}$ 径プラスティックシャーレに1,000個の細胞 を植え込双，14日間培龊後ホルマリン（和光純薬）固定 しギムザ（和光純薬）染色を行った。

5）口腔癌紐胞の增殖に及ぼす EGF ならびに FGF の影脷

扁平上皮癌細胞上唾液腺由来腺癌細胞は RD $6 \mathrm{~F}$ の条 件下, $2 \times 10^{4} / \mathrm{ml}$ の細胞密度でコラーゲンコートした 24 ウェルプレートに植光込み, 各濃度の EGF, acidic FGF, basic FGF (R\&D System Inc., bovine brain)
を加えた。扁平上皮癌細胞は 5 日間, 唾液腺由来腺癌細 胞は 4 日間培養後の細胞数を計測した。

6) EGF ならびに FGF の受容体解析

$\mathrm{EGF}$ および FGF の [ $\left.{ }^{125} \mathrm{I}\right]$ 標識は， Na [ $\left.{ }^{125} \mathrm{I}\right]$ (Amersham International, USA) を用いてクロラミン T 法 ${ }^{25)}$ により行った。比活性は EGF $7.25 \times 10^{4} \mathrm{cpm} / \mathrm{ng}$, acidicFGF $1.28 \times 10^{5} \mathrm{cpm} / \mathrm{ng}$ であった。

$\mathrm{EGF}$ 受容体の検索は $0.2 \%$ バラホルムアルデヒド (Taab laboratories, England) で5 分間固定した各細胞 を, $2 \times 10^{4}$ /well の細胞密度で96ウェルプレート（V\&P SCIENTIFIC, INC., USA) の各グラスファイバーフ ィルター上に接種し, RD buffer(RD, 25 mM HEPES, $\left.1 \mathrm{mg} / \mathrm{ml} \mathrm{BSA}, 0.02 \% \mathrm{NaN}_{3}, \mathrm{pH} 7.4\right)$ で洗浄した。 $5 \mathrm{pg}$ から $20 \mathrm{ng}$ の 12 種類の [ $\left.{ }^{125} \mathrm{I}\right]$ 濃度の標識された $\mathrm{EGF}$ を加え, 最終容量を $100 \mu l$ として 2 時間室温でイ ンキュベートした，RD buffer で洗浄後, 細胞に結合し た [125 I] EGF の放射活性を総結合量としてオートウェ ルガンマーシステム（ARC 600, Aloka) を用いて测定 した。総結合量から非特異的結合量の差を特異的結合量

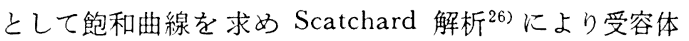
数ならびに解離定数を求めた.

EGF の受容体解析は, 各細胞を 48 ウェルプレートに 植光込み 2 日間培養した後， [ $\left.{ }^{125} \mathrm{I}\right]$ acidic FGF と種々 の濃度の acidic FGF を加えて 2 時間インキュベートし た. 3 回洗浄後, 細胞に結合した放射活性をオートウェ ルカンマーシステムを用いて測定し，Scatchard 解析を 行った。

7 ）口腔粘膜由来正常上皮細胞の増殖に対する $\mathrm{EGF}$ と FGF の働き

口腔粘膜由来正常上皮細胞をコラーゲンコートした 24 ウェルプレートに $10^{4} / \mathrm{ml}$ の細胞密度で植え込み, 1.2 $\mathrm{nM}$ acidic FGF 存在下で $0 \sim 10 \mathrm{nM}$ の $\mathrm{EGF}$ ，あるい は $3 \mathrm{nM} \mathrm{EGF}$ 存在下で0〜 $10 \mathrm{nM}$ の acidic FGF を加 えて10日間培着後の細胞数を計測した。

\section{結果}

\section{1. 無血清培養下での細胞增殖能の検索}

無血清培差下での扁平上皮癌細胞ならびに喠液腺由 来腺癌細胞の細胞倍加時間 (T.d.) は, UEDA 30.6, NAKATA 23.9, KANETSUKI 29.9, HSG 22.2, HSY 31.9，ACC 22.0時間であった。これらは10\%牛 胎罗血清添加時の倍加時間と同等の增殖であった（図 1，2）. ACC 細胞は無血清培福条件下に樹立され，血清 添加培地での增殖は抑制された（未発表データ）。一方， 正常上皮細胞は MCDB5F $\mathrm{MCDB} 6 \mathrm{~F}$ の培荃条件て は增殖できなかった。

このよ5にロ腔癌細胞は insulin, transferrin, 2-aminoethanol, $\beta$-mercaptoethanol, sodium selenite および 

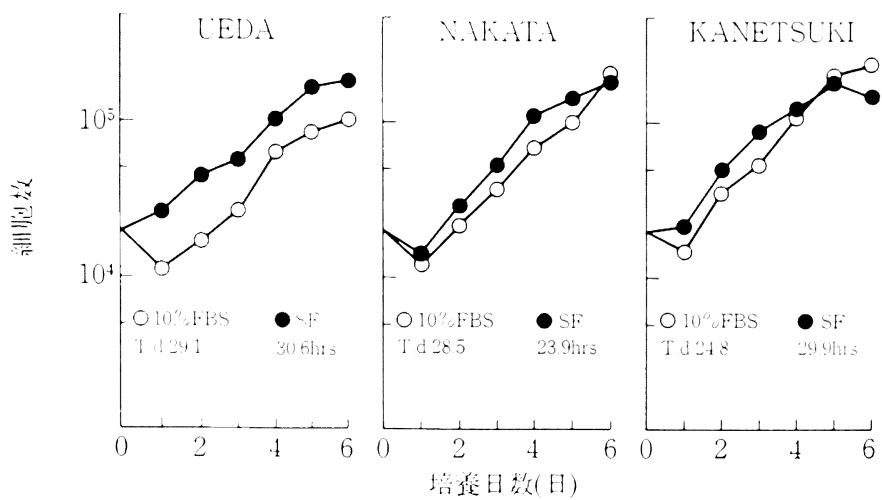

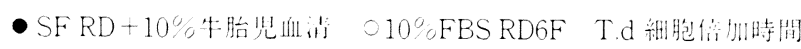

図 1 扁平上皮癌細胞の增殖曲線
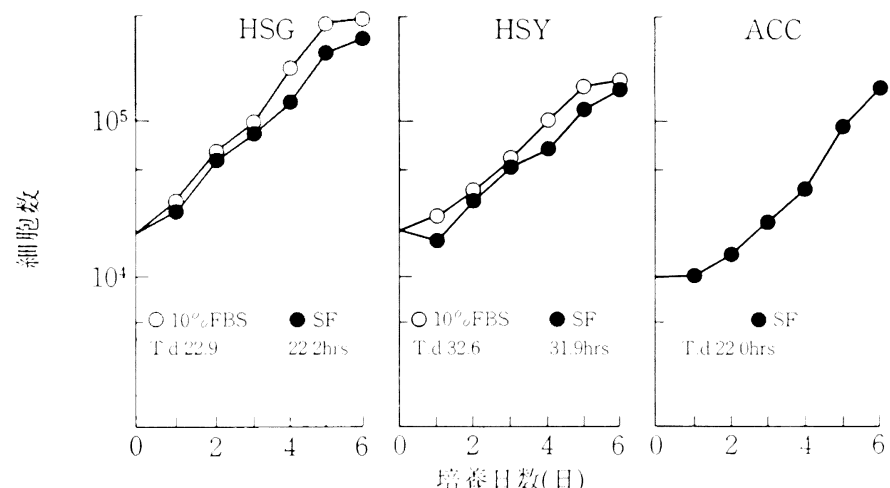

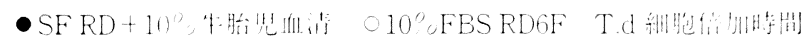

図 2 唾癄腺由米腺癌細胞の增殖曲線

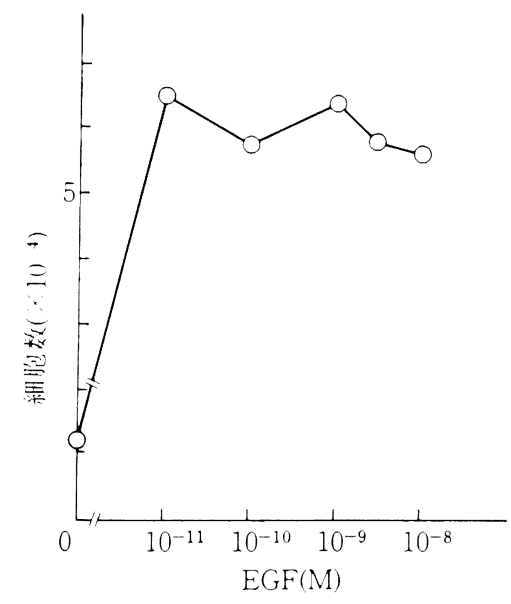

図3口腔粘膜由来正常上皮紐胞（継代 9 代目）の增殖に及ぼす $\mathrm{EGF}$ の影䈏

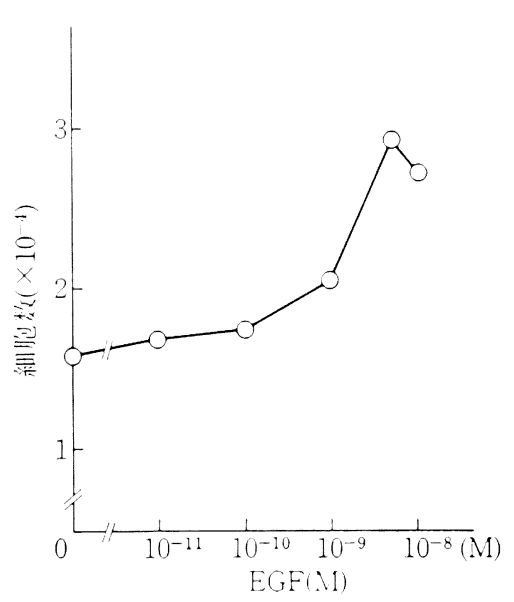

図4唾液腺由来正常上皮勫胞（継代 3 代 日) の增殖に及活す $\mathrm{EGF}$ の影響 


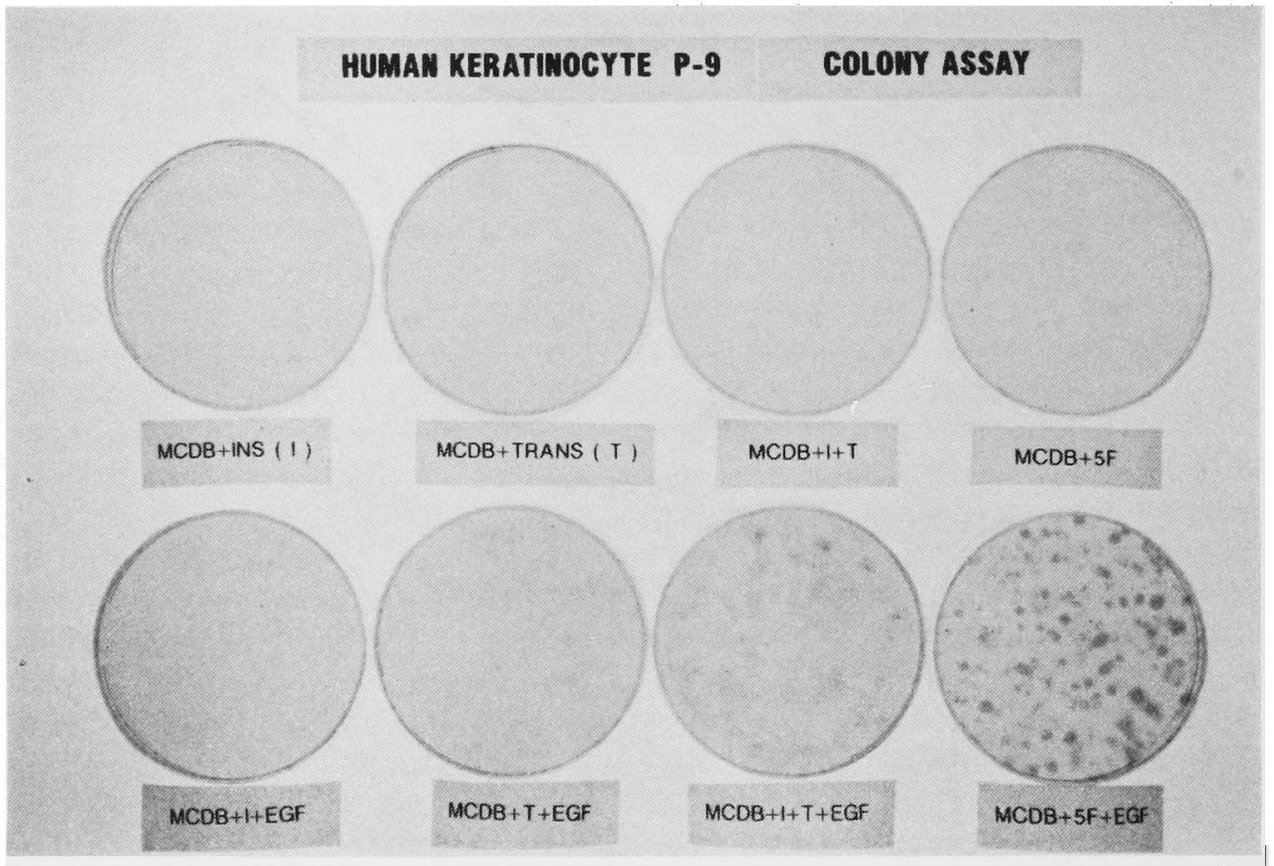

写真 1 口腔粘膜由正常上皮細胞を用いたコロニーアッセイ

insulin, transferrin, 2-aminoethanol, 2-mercaptoethanol, sodium selenite 扰よび EGF の要求性 を検索した。

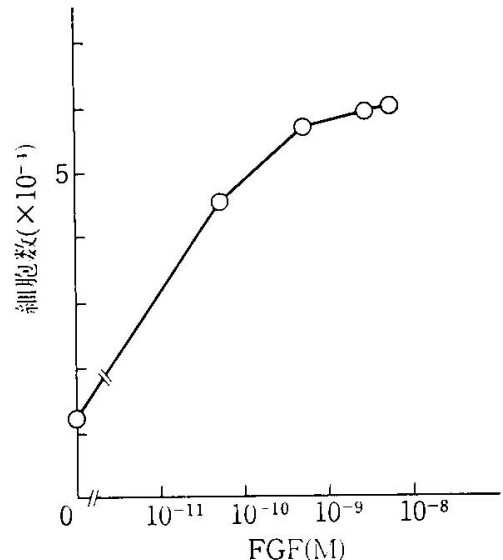

図 5 口腔粘膜由来正常上皮細胞（継代 9 代目）の增殖に及ぼすFGF の喝㸷

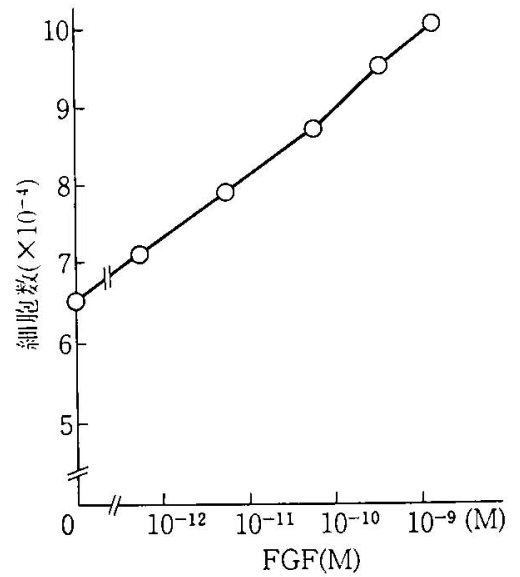

図 6 唾液腺由来正常上皮稩胞（継代 3 代

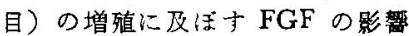

oleic acid を含む RD6F で增殖できるが，正常上皮細 胞は $6 \mathrm{~F}$ を含さ無血清培地では増殖できないことがわか ったまた，DME，Ham F12，RPMI 1640 それぞれ 単独あるいはそれぞれ混合した種々の基礎培地を用いて 同様の検索を行ったが，RD 培地が最もすぐれていた。
2. EGF ならびに FGF の細胞增殖に及ばす影響とそ の受容体解析

1）正常上皮細胞の增殖に及ぼす EGF ならびに FGF の影響

EGF は口腔粘膜および喠液腺由来正常上皮細胞の增 殖を促進した。 その最大増殖促進濃度は口腔粘膜由来正 


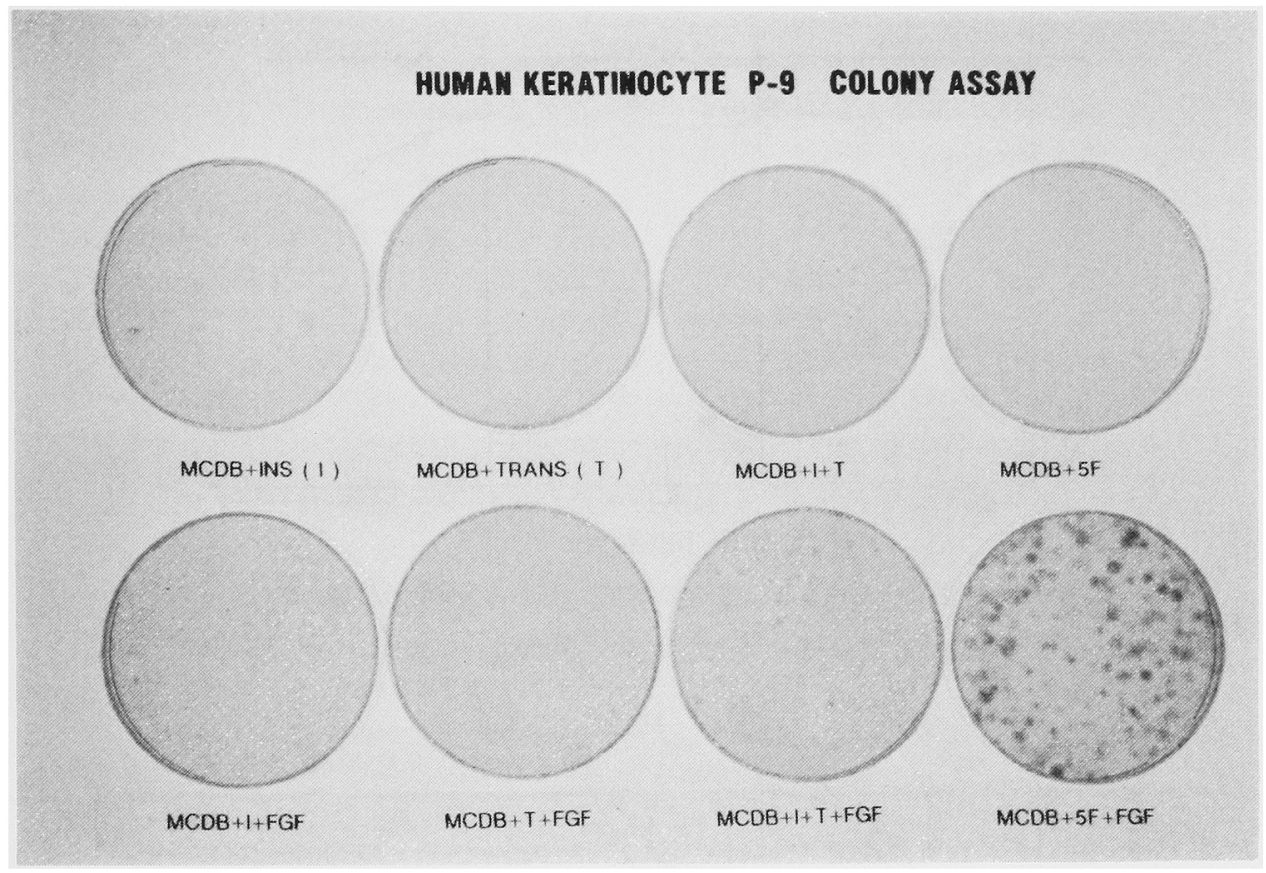

写真 2 口腔粘膜由来正常上度細胞を用いたコッニーアッセイ

insulin, transferrin, 2-aminoethanol, 2-mercaptoethanol, sodium selenite おょび FGF の要求性 を检索した。

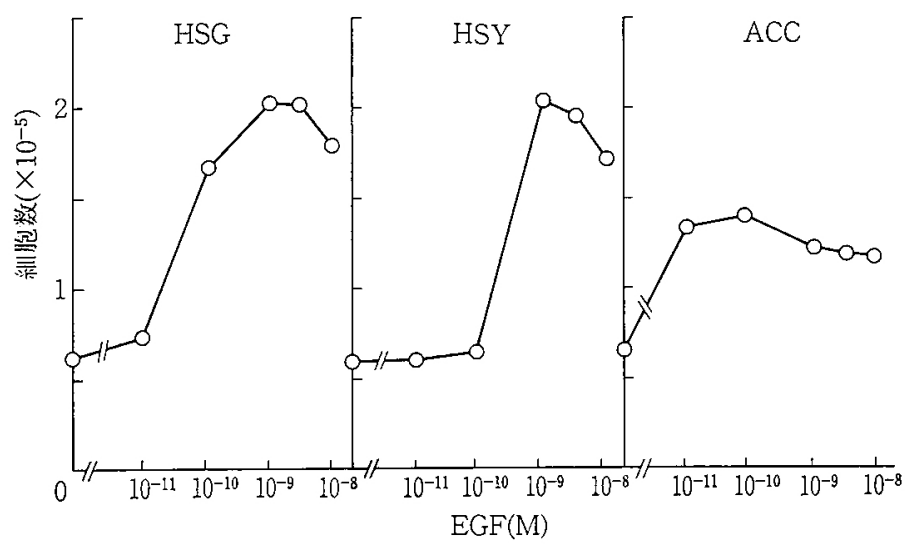

図 7 唾液腺由来腺癌細胞の増殖に及ぼ $\mathrm{EGF}$ の影響

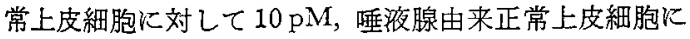
対して3nM であった（図3，4）.

FGF むこれら正常上皮細胞の增殖を促進し， その最 大増殖促進濃度は1 nM であった（图 5，6）。

口腔癌細胞は RD6F の無血清培盖条件で增殖可能で あったが，正常上皮細胞は増殖できなかった，そこで同 細胞の insulin, transferrin, 2-aminoethanol, 2-mercaptoethanol, sodium selenite, EGF ならびに FGF の要
求性を colony assay 法を用いて検索した，その結果， 正常上皮細胞の増殖にとって EGF あるいは FGF は必 須であり，EGF 特よび FGF 非存在下では增殖能を稚 持することはできないことがあきらかとなった（写真 1,2).

2）口腔癌細胞の増殖に及ぼす EGF の影響およびそ の受容体解析

唾液腺由来腺癌細胞の増殖は EGFにより濃度依存的 


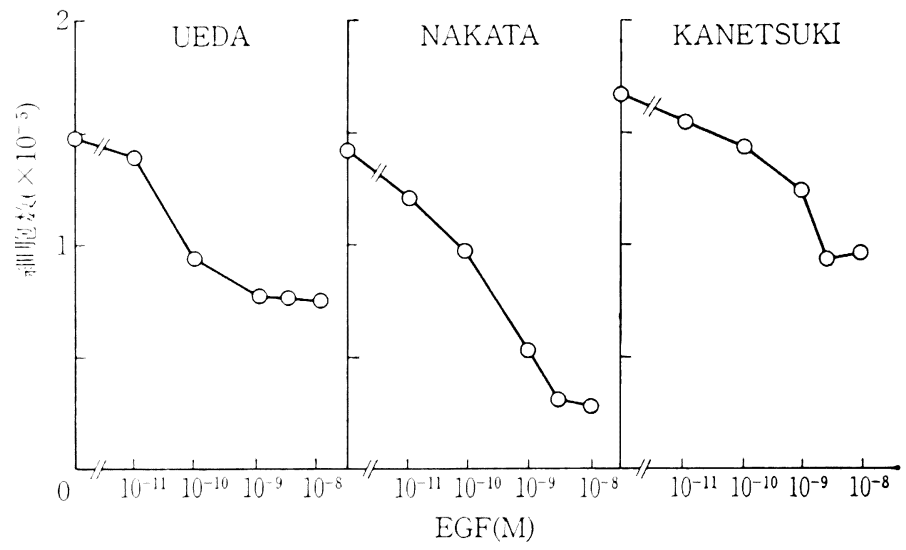

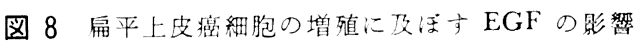

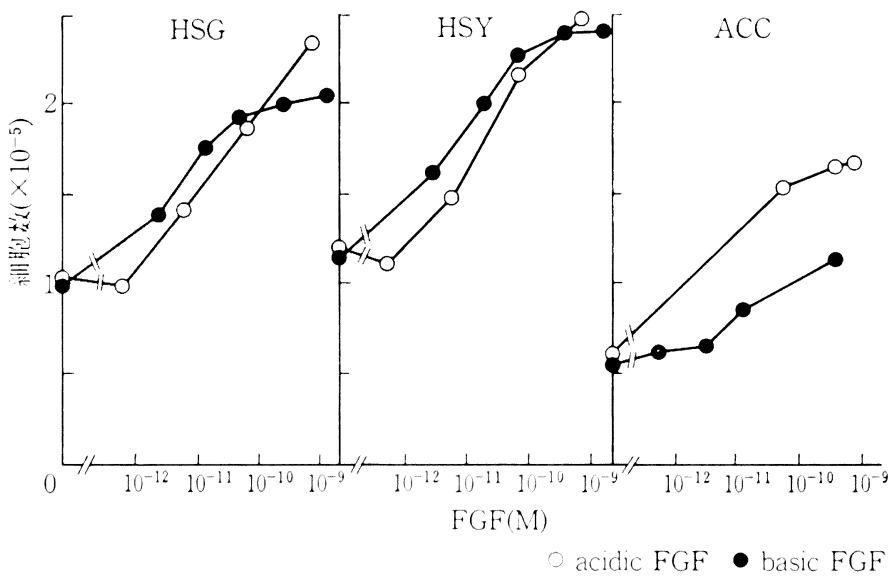

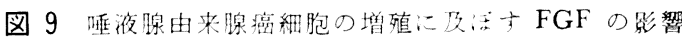

に促進され，その最大促進濃度はHSGに対して $3 \mathrm{nM}$, HSY に対して1nMであった（図７）。一方，扁平上皮 癌細胞の增殖は EGFにより著明に抑制され，その最大 抑制濃度は UEDA $1 \mathrm{nM}$, NAKATA $3 \mathrm{nM}$, KANETSUKI $3 n M$ てあった(図 8).この結果から, 口腔由来 扁平上皮癌科胞の增殖は, 他細胞の增殖を促進する $\mathrm{EGF}$ 澧度て著明に抑制されることがあきらかとなった。

口腔由来雇平上皮虞細胞の $\mathrm{EGF}$ 受容体数は1.9 3.2 $\times 10^{5} /$ cell で， 口腔粘膜由来正常上皮細胞の受容体数 $1.7 \times 10^{5} /$ cell と市きらかな差を認めなかった。また， いすれも親和性の異なる 2 偖類の EGF 受容体を有して いた（表1）.

一方，EGF 受容体を過剩発現している れているA431 細胞はこれら細胞の10２0倍の受容体数 を有していたここの結果から，今四奏娩に用いた口腔由
表 1 口腔粘膜由米正常上皮細胞と口腔癌細胞の EGF 受容体数扣上び親和性

\begin{tabular}{l|r|r|r}
\hline \multirow{2}{*}{} & \multirow{2}{*}{ 受容体数 } & \multicolumn{2}{|c}{ 親和性 } \\
\cline { 3 - 4 } & & 低親和性 & 高親和性 \\
\hline UEDA & $1.9 \times 10^{5}$ & $3.7 \times 10^{-9}$ & $9.2 \times 10^{-11}$ \\
NAKATA & $1.4 \times 10^{5}$ & $3.8 \times 10^{-9}$ & $1.1 \times 10^{-10}$ \\
KANETSUKI & $3.2 \times 10^{5}$ & $8.6 \times 10^{-9}$ & $3.7 \times 10^{-10}$ \\
口腔由来 & $1.7 \times 10^{5}$ & $9.4 \times 10^{-9}$ & $1.3 \times 10^{-10}$ \\
正常上皮細胞 & & & \\
HSG & $1.4 \times 10^{5}$ & $8.0 \times 10^{-9}$ & $2.2 \times 10^{-10}$ \\
HSY & $6.7 \times 10^{4}$ & $9.1 \times 10^{-9}$ & $1.0 \times 10^{-10}$ \\
\hline A 431 & $4 \times 10^{6}$ & $2.5 \times 10^{-9}$ & $2.9 \times 10^{-10}$ \\
\hline
\end{tabular}




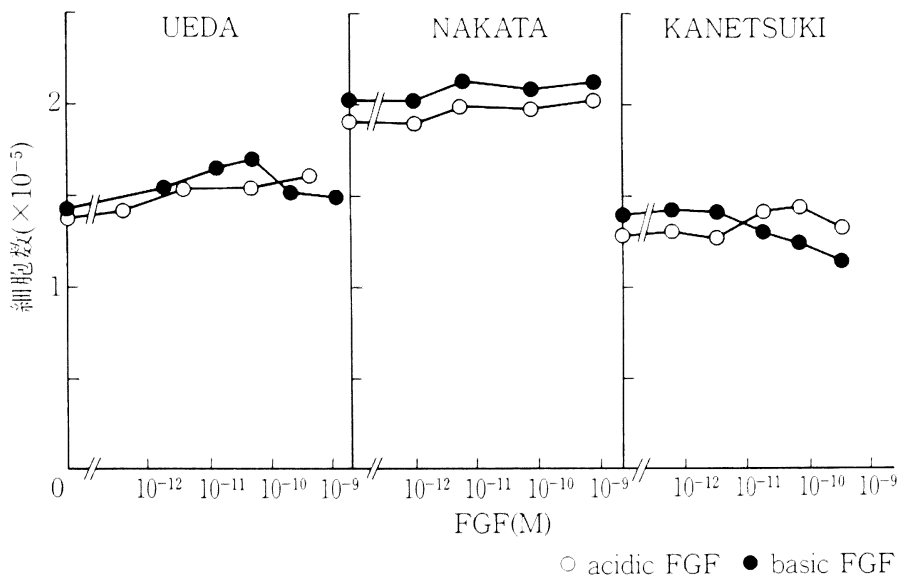

図 10 扁平上皮癌細胞の增殖に及ぼす FGF の影琶

表 2 FGF 受容体解析結果

\begin{tabular}{l|c|c|c}
\hline & \multirow{2}{*}{ 受容体数 } & \multicolumn{2}{|c}{ 親和性 } \\
\cline { 3 - 4 } & & 低親和性 & 高親和性 \\
\hline A431 & $4.3 \times 10^{3}$ & & $6.7 \times 10^{-11}$ \\
NAKATA & $2.5 \times 10^{3}$ & & $4.6 \times 10^{-12}$ \\
KANETSUKI & $4.5 \times 10^{3}$ & & $8.0 \times 10^{-12}$ \\
HSG & $3.9 \times 10^{3}$ & $6.0 \times 10^{-10}$ & $4.5 \times 10^{-11}$ \\
\hline
\end{tabular}

来扁平上皮癌細胞には EGF 受容体の過剩発現は生じて いないことがあきらかとなった。

EGFにより増殖促進された HSG, HSY 細胞の EGF 受容体数も他細胞と比較して著明な差を認めなかった。 また，いずれも親和性の異なる2 種類の受容体が存在し ていた（表１）.

さらに扁平上皮癌細胞の增殖抑制浱度之唾液腺由来腺 癌細胞の増殖促進濃度は, それぞれの低親和性受容体の 解離定数と一致していた。

3）口腔癌細胞の增殖に及洔すFGF の影艟とその受 容体解析

FGF は口腔粘膜ならびに唾液腺由来正常上皮細胞ば か门でなく，唾液腺由来腺癌細胞の増殖も促進した（図 9).これら細胞に対する FGF の最大增殖促進濃度は $1 \mathrm{nM}$ であった。一方, 扁平上皮癌細胞の增殖に対して, FGF はあきらかな影響を与えなかった（図10）。

扁平上皮癌細胞は FGF に対して応答を示さなかった ことから, 同細胞にはFGF 受容体が存在していない可 能性が考えられた。しかし受容体解析の結果, 扁平上皮 癌細胞は唾液腺癌細胞と同程度の FGF 受容体を有して いることがあきらかとなった（表 2 ）。扁平上皮癌細胞
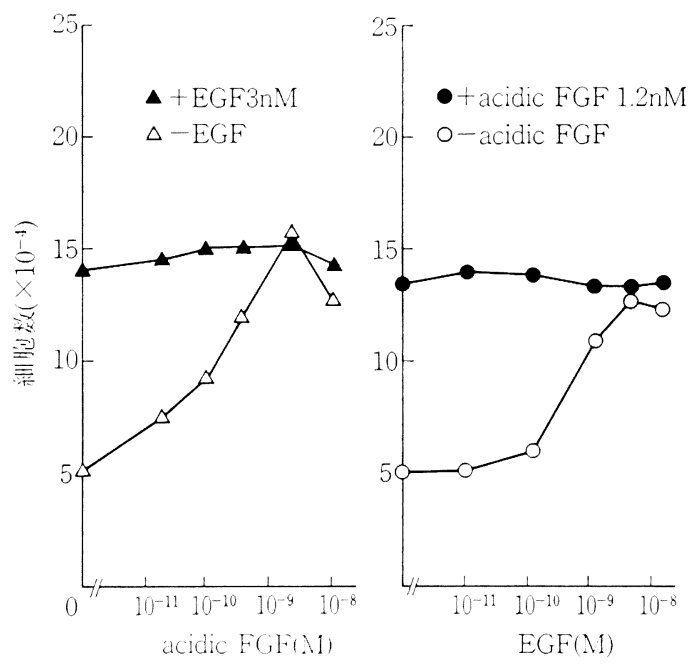

図 11 七ト正常上皮細胞の增殖に及ぼ $\mathrm{EGF}$ と FGF の相互作用

には1種類の高親和性受容体を楒めその数は2.5〜4.5× $10^{3} /$ cell であった. FGF により增殖促進される HSG 細胞には親和性の異なる 2 種類の FGF 受容体が存在 し，その数は $3.9 \times 10^{3} /$ cell であった。この結果から， 扁平上皮癌細胞にはF F に対しても応答異常が生じて いることがあきらかとなった。

4) 口腔粘膜由来正常上皮細胞の増殖に対する $\mathrm{EGF}$ と FGF の働き

$1.2 \mathrm{nM}$ の acidic FGF 存在下で EGF の增殖に及ほ す影響を検索した結果, 最大增殖時の細胞数は $1.2 \mathrm{nM}$ の acidic FGF 単独による細胞数と同じであった（図 
11).また，同様に $3 n \mathrm{M}$ の $\mathrm{EGF}$ 存在下で acidic FGF の影留を検索したが最大增殖時の細胞数は $3 \mathrm{nMIEG}$ 単独による細胞数と同じであった。この結果から、ヒト 正常上皮細胞の增殖に対して，EGFと FGFはまった く同じ働きをしていることがわかった。

\section{考察}

本研究において，適切な基礎培地に適切なホルモンや 紐胞増殖因子を加えることにより腫境細胞のみならず正 常上皮細胞をも継代維持することができることがあきら かとなった。

血清中にはホルモン, 細胞增殖因子, その結合蛋白や 未知の蛋白成分，コレステロールや脂肪酸などの脂質成 分, 糖蛋白などが存在している.今回, 口腔粘膜由来正 常上皮細胞の培着に用いた豠血清培地の蛋白成分は， insulin, transferrin で蛋白量は $12 \mu \mathrm{g} / \mathrm{m} /$ であった。一 方, 10\% 血清添加培地の蛋白量は $65 \sim 80 \mathrm{mg} / \mathrm{ml}$ であ り，しかもその大部分は未知蛋白である。

正常上皮細胞は血清添加培地では継代維持が困難であ った，一方血清中心は TGF- $\beta^{27)}$ や䑨本らが見い出した $\mathrm{TGF}-j$ と異なる上皮細胞増殖抑制因子 ${ }^{28)}$ が存在するた わ，正常上皮緗胞の增殖は抑制されたと考えられる。

正常上皮緗胞の細胞增殖因子要求性を colony assay を用いて検討した結果，EGF と FGFはともにその增 殖を促進した。しかも，それらが存在しない条件では生 存できなかったことから，EGF あるいは FGF は正常 上皮細胞の増殖にとって必須因子であることがあきらか となった。

一般にヒト正常線維芽細胞を用いた検索ていは，細胞集 団倍加数 (population doubling level, PDL) の增加とと もに紏胞增殖能を失っていくことが報告されている29). 今回の奏験で，口腔粘膜由来正常上皮細胞之唾液腺由来 正常上皮細胞に対与る, EGF と F GF の増殖促進濃度 が異なった。これは口腔粘膜由来正常上皮紐胞は幼若年 者の口腔粘膜, 唾液腺由来正常上皮細胞は老壮年者の顎 下腺を用いたためと考えられた。また口腔粘膜と比較し て顎下腺は高度に分化した器官であることから上皮細胞 の增殖能に差が生じた可能性も考えられた。

一方，扁平上皮癌緗胞や唾液腺由来腺癌細胞は RD6F の条件でも10\%牛胎児血清涯加時と同様の增列を示し， その增殖にとって EGF や FGFは必須ではなかった。 このことから, 口腔癌細胞は正常上皮細胞と比較して $\mathrm{EGF}$ や FGF の要求性が低下, あるい:消失している と考觉られた。

唾湤腺由来腺癌細胞は, $\mathrm{EGF}$ 户 FF に対して唾液 腺由来正常上皮細胞と同じ增殖動態を示した。一方，扁 平上皮癌紏胞の增殖は正常上皮細胞の增殖を促進する濃 度の EGFで著明に抑制され，正常細胞とは相反する応
答を示した。また，FGF は扁平上皮癌細胞の增殖に対 してなんら影秏を与えなかった。

このよ5に, 扁平上皮癌細胞は口腔粘膜由来正常上皮 細胞と比較して，EGF および FGF に対する応答異常 が生じていることがあきらかとなった。今回 $\mathrm{EGF}$ FGF のとトロ腔粘膜由来正常上皮細胞への働きを詳細 に検索するため，EGF あるい: FGF 単独で同細胞の 継代を試及た，EGF 単独では 3 代以上継代すると細胞 は膨化, elongationなとの分化傾向を示し增殖能を失っ てしまった。しかし，FGF 単独では增殖は遅いものの 継代を重社ても敷石状の均一な細胞群の増殖を認めた （未発表データ）。また，碳本は正常マウス唾液腺上皮細 胞のアミラーゼ産生を分化の指標として免疫組織学的に 検索し，FGF 存在下で培羡した細胞ではアミラーセ陵 性であったが, EGF 存在下で培盖した細胞はアミラー

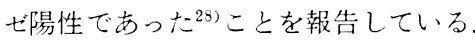

一方, Rosdy ${ }^{30}$ ( は扁平上皮癌 $\mathrm{A} 431$ 細胞に対する $\mathrm{EGF}$ の影響を，上皮細胞の分化の指標である cornified envelope $^{31)}$ の前駆物質である involucrin ${ }^{32)}$ の蓄積を指摽と して検索し，EGFはA431 細胞の分化を誘導したと報 告している。著者らの結果ならびにこれらの報告から， EGF は正常細胞に対しては增殖のみならず分化促進に も動くが, 扁平上皮癌細胞に対しては分化促進にの又働 き結果的に增殖抑制している可能性が考えられた。

扁平上皮癌細胞の增殖が $\mathrm{EGF}$ により抑制されるとい 万事実 ${ }^{33 \sim 36)}$ はすでに報告されている。 そのほとんどは,

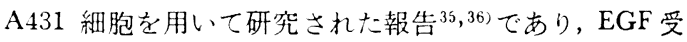
容体の過剩発現と EGF による增殖抑制作用は密接に関 係しているとされてきた。しかし，今回実験に用いた口 腔由来扁平上皮癌細胞々口腔粘膜由来正常上皮細胞の間 で, EGF 受容体の数や親和性に差を見い出すことはで きず，扁平上皮癌細胞の $\mathrm{EGF} に よ る$ 增殖抑制は $\mathrm{EGF}$ 受容体の過剩発現だけでは説明できないことがあきらか となった。

さらに, 今回の実験結果から他細胞と比較して, 扁平 上皮癌細胞の $\mathrm{EGF}$ 受容体や FGF 受容体の受容体数, 親和性に異常を認めなかったにもかかわらず EGFゃ FGF に対与る応答異常が存在したことから，制平上皮 癌細胞には EGF 受容体および FGF 受容体の機能異常 あるいは受容体以降の情報伝達系に異常が生じている可 能性が示㖫された。

今回, 口腔粘膜由来正常上皮細胞の $\mathrm{EGF}$ および FGF 共存下での最大増殖時の細胞数は, それぞれ単独の最大 增殖時の細胞数と同じであった。この結果から, EGF とFGF は正常上皮細胞に対して受容体は異なるが共通 の情報伝達経路を介して作用している可能性が考えられ た。このように異なる受容体を持つ細胞増殖因子の情報 が同じ経路を介して伝達されることは他の細胞增殖因子 でも見い出されており，TGF- $\beta^{37)}$ interleukin-1 ${ }^{38)}$ 
PDGF の情報経路を介して線維芽細胞の増殖を促進し ていることが報告されている。したがって，扁平上皮癌 細胞の EGFによる增殖抑制と FGF に対する不応答は 密接に関係している可能性が考えられた。

Todaro と Sporn'5)らはウス肉腫ウイルスや SV 40 ウイルスによって形質転換した線維芽細胞は EGF の要 求性が低くなることから TGF- $\alpha$ を見い出し ${ }^{39}$, autocrine 説桌を提唱した。 Heldin ら ${ }^{40)}$ 己腫瘍細胞の autonomous な增殖のメカニズムに同様の説明を加え, 形質 転換した線維芽細胞は自ら PDGF を自己増殖促進因子 として産生することにより自律增殖性を獲得しているこ と

今回用いた口腔由来扁平上皮癌紐胞の培盖上清中に FGF 様活性を見い出している（未発表データ）。また岡 本らは A431 細胞は basic FGF 様因子を培荃上清中に 産生していることを報告している ${ }^{42}$ さらに A431 細胞 には細胞膜貫通ドメインを有する $\mathrm{TGF}-\alpha$ を産生してお り細胞膜上に TGF- $\alpha$ を発現していることがあきらかに されている43) したがって, 扁平上皮癌細胞はこれら因 子を産生することにより自律增殖性を獲得しているもの と考えられた。また唾液腺由来腺癌細胞は $\mathrm{EGF}$ や F GF によって增殖促進されたが, それらの要求性は唾液腺由 来正常上皮細胞と比較してあきらかに低かった。これは 同腺癌細胞が $\mathrm{EGF}^{44}$ あるいは $\mathrm{EGF}$ 様因子 45 F FF 様因子 ${ }^{46)}$ を産生しており，唾液腺由来腺癌細胞の自己増 殖促進因子として動いているためと考元られた。

以上, 無血清培地を用いて, 正常上皮細胞と口腔癌細 胞の細胞増殖動態の違いをあきらかにした。また細胞の 癌化または癌化の過程に EGF 户 FGF などの細胞増殖 因子が深く関与していることが示㗎された。 さらにここ れら細胞增殖因子の作用を制御することにより癌の增殖 を抑制する口腔癌の内分泌的治療が可能になると考兄ら れた。

総

1. ヒトロ腔粘膜および唾液腺由来正常上皮細胞はそ れぞれ m’-MCDB5F および $\mathrm{m}$-MCDB6F に, EGF あるいはFGF を加えた条件で継代維持が可能であっ た。 ヒト口腔由来扁平上皮癌細胞之唾液腺由来腺癌細胞 は RD6F 培地で, 10\% 牛胎児血清添加時と同等の增殖 を示した。

2. EGF および FGF はヒト口腔粘膜由来正常上皮細 胞, ヒ上唾液腺由来正常上皮細胞および唾液腺由来腺癌 細胞の增殖を濃度依存的に促進した。特に口腔粘膜およ び唾液腺由来正常上皮細胞の増殖にとって，EGF ある いはFGFは必須であった。

3. EGF は扁平上皮癌細胞の增殖を著明に抑制したが FGF は影響を与えなかった。しかし，扁平上皮癌細胞

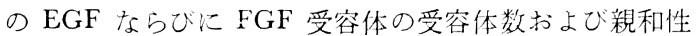
は他細胞のそれらと比較して著明な差を認めなかった。 このことから，扁平上皮癌細胞には $\mathrm{EGF}$ および FGF に対寸る応答異常が存在すると考えられた。

\section{引用 文 献}

1) Waterfield, M.D., Scrace, G.T. et al. . Plateletderived growth factor is structually related to the putative transforming protein p 28sis of simian sarcoma virus. Nature 304: $35-39$ 1983.

2) Downward, J., Yarden, Y., et al.: Close similarity of epidermal growth factor receptor and $\mathrm{v}$-erbB oncogene protein sequence. $\mathrm{Na}$ ture 307: 521-527 1984.

3) DeLarco, J.E. and Todaro, G.J.: Growth factors from murine sarcoma virustransformed cells. Proc Natl Acad Sci USA 75: 400140051978.

4) Waldmann, T.A., Greene, W.C., et al.: Function and phenotypic comparison of human $\mathrm{T}$ cell leukemia/lymphoma virus positive adult $\mathrm{T}$ cell leukemia with human $\mathrm{T}$ cell leukemia/lymphoma virus negative Sezary leukemia, and their distinction using anti-Tac: Monoclonal antibody identifying the human receptor for $\mathrm{T}$ cell growth factor. J Clin Invest 73: 1711-1718 1984 .

5) Sporn, M.B. and Todaro, G.J.: Autocrine secretion and malignant transformation of cell. N Engl J Med 303: 878-880 1980.

6) Sporn, M.B. and Roberts, A.B.: Autocrine growth factors and cancer. Nature 313: 7457471985.

7) Masui, T., Wakefield, L.M., et al.: Type- $\beta$ transforming growth factor is the primary differentiation-inducing serum factor for normal human bronchial epithelial cells. Proc Natl Acad Sci USA 83: 2438-2442 1986.

8) Rutherford, R.B. and Ross, R.: Platelet factors stimulate fibroblasts and smooth muscle cells quiscent in plasma serum to proliferate. J Cell Biol 69: 196-203 1976.

9) Hayashi, I. and Sato, G.H.: Replacement of serum by hormones permits growth of cells in a defined medium. Nature 259: 132 1341976.

10) Barnes, D., McKeehan, W.L., et al.: Cellular endocrinology: Integrated physiology in vitro. In Vitro Cell Dev Biol 23: 659-662 1987.

11) Tsao, M.C., Walthall, B.J., et al.: Clonal growth of normal human epidermal keratino- 
cytes in a defined medium. J Cell Physiol 110: 219-229 1982.

12) Moore, G.E., Gerner, R.E., et al.. Culture of normal human leukocyte. JAMA 199: 5195241967.

13) Dulbecco, R. and Freeman, G.: Plaque production by the polyoma virus. Virology 8 : 396-397 1959.

14) Sato, J.D., Kawamoto, T., et al.: Cholesterol requirement of $\mathrm{P} 3-\mathrm{X} 63-\mathrm{Ag} 8.653$ and $\mathrm{X} 63-\mathrm{Ag}$ 8. 653 mouse myeloma cells for growth in vitro. J Exp Med 165: 1761-1766 1987.

15) Myoken, Y., Okamoto, T., et al.: An alternative method for the isolation of NS-1 hybridoma using cholesterol auxotrophy of NS-1 mouse myeloma cells. In Vitro Cell Dev Biol 25: 477-480 1989.

16) Kawamoto, T., Sato, J.D., et al.. Development of a serum-free medium for growth of NS-1 mouse myeloma cells and its application to the isolation of NS-1 hybridoma. Anal Biochem 130: 445-453 1983.

17) Yuspa, S.H. and Harris, C.C.. Altered differentiation of mouse epidermal cells treated with retinyl acetate in vitro. Exp Cell Res 86: 95-105 1974.

18）宮内忍, 諸山隆正, 他：七卜口底癌由来細胞 株 (UEDA-1) の樹立. 日口外誌 31：134713511985.

19) Miyauchi, S., Moroyama, T., et al.: Malignant tumor cell line produce interleukin-1like factor. In Vitro Cell Dev Biol 24: 7537581988.

20) Fabricant, R.X., DeLarco, J.E., et al.: Nerve growth factor receptors on human melanoma cells in culture. Proc Natl Acad Sci USA 74: 565-569 1977.

21) Shirasuna,K., Sato, M., et al.: A neoplastic epithelial duct cell line established from an irradiated human salivary gland. Cancer 54 : 745-752 1981.

22) Yanagawa, T., Hayashi, Y., et al.: Generation of cells with phenotypes of both intercalated duct-type and myoepithelial cells in human parotid gland adenocarcinoma clonal cells grown in athymic nude mice. Virchows. Ach. [B] 51: 185-195 1986.

23) Okamoto, T., Myoken, Y., et al.: Establishment and characterization of Adenoid cystic carcinoma cell line $\mathrm{ACC}$. (manuscript in preparation)

24) Crabb, J.W., Armes, L.G., et al.: Characterization of multiple form of prostatropine (prostate epithelial growth factor) from bovine brain. Biochem Biophysic Res Commun 136:
1155-1161 1986.

25) Hunter, W.M. and Greenwood, F.C.: Preparation of iodine-131 labelled human growth hormone of high specific activity. Nature (Lond.) 194: 495-496 1962.

26) Scatchard, G.. The attractions of protein for small molecules and ions. Ann NY Acad Sci 51: 660-672 1949.

27) Roberts, A.B., Anzano, M.A. ,et al.: Purification and properties of a type- $\beta$ transforming growth factor from bovine brain kidney. Biochemistry 22: 5092-5098 1983.

28）薮本正文，岡本哲治，他：正常、ウス顎下腺上 皮細胞の無血清培湌下での株化。日口外誌 36 : 791-801 1990.

29) Hayflick, L. and Moorhead, P.S.. The serial cultivation of human diploid cell strains. Exp Cell Res 25: 585-621 1961.

30) Rosdy, M.: Opposite effects of EGF on involucrine accumulation of A431 keratinocytes and a variant which is not growtharrested by EGF. In Vitro Cell Dev Biol 24: 1127-1132 1988.

31) Green, H.: Terminal differentiation of cultured human epidermal cells. Cell 11: 4054161977.

32) Watt, F.M. and Green, H.: Involucrin synthesis is correlated with cell size in human epidermal cultures. J Cell Biol 90: 738-742 1981.

33) Kamata, N., Chida, K., et al.: Growthinhibitory effects of epidermal growth factor and overexpression of its receptors on human squamous cell carcinoma in culture. Cancer Res 46: 1648-1653 1986.

34) Ponec, M., Weerheim, A., et al.: Proliferation and differentiation of human squamous carcinoma cell lines and normal keratinocyte: Effects of epidermal growth factor, retinoid, and hydrocortisone. In Vitro Cell Dev Biol 24: 764-769 1988.

35) Barnes, D.W.: Epidermal growth factor inhibits growth of A431 human epidermoid carcinoma in serum-free cell culture. J Cell Biol 93: 1-4 1982.

36) Gill, G.N. and Lazar, C.S.: Increased phosphotyrosine content and inhibition of proliferation in EGF-treated A431 cells. Nature 293: 305-307 1982.

37) Loef, E.B., Proper, J.A., et al.: Induction of c-sis mRNA and activity similar to plateletderived growth factor by transforming growth factor- $\beta$ : A proposed model for indirect mitogenesis involving autocrine activity. Proc Natl Acad Sci USA 83: 2453-2457 1986. 
38) Raines, E.W., Dower, S.K., et al.: Interleukin 1 mitogenic activity for fibroblast and smooth muscle cells is due to PDGF-AA. Science 20: 393-396 1989.

39) Todaro, G.J., DeLarco, J.E., et al.: Sarcoma growth factor and transforming peptides produced by human cells: interactions with membrane receptors. Federation Proc 41: 2995-3003 1982.

40) Heldin, C.-H. and Westermark, B.: Growth factors: Mechanism of action and relation to oncogene. Cell 37: 9-20 1984.

41) Heldin, C.-H., Wisateson, A., et al.: Interaction of platelet-derived growth factor with its fibroblast rceptor. J Biol Chem 257: 421642211982.

42) Okamoto, T., Wu, D., et al.: Production of a basic EGF like growth factor by human epidermoid carcinoma cells. In Vitro Cell Dev Biol 23: 411987.
43) Wu, D., Wang, L., et al.: Membrane-bound transforming growth factor- $\alpha$ as an autocrine factor for A431 human epidermoid carcinoma cells. Oncogene 1991. (in press)

44) Sato, M., Yoshida, H., et al.: Expression of epidermal growth factor and transforming growth factor $-\beta$ in a human salivary gland adenocarcinoma cell line. Cancer Res 45: 6160-6167 1985.

45) Kurokawa, R., Kyakumoto, S., et al.: Autocrine growth factor in defined serum-free medium of salivary gland adenocarcinoma cell line HSG. Cancer Res 49: 5136-5142 1989.

46) Osaki, T., Okamoto, T., et al.: Human salivary gland adenocarcinoma cells (HSG) produce a basic-FGF like growth factor as an autocrine growth factor. Jpn J Can Res (抄): 1851989 . 